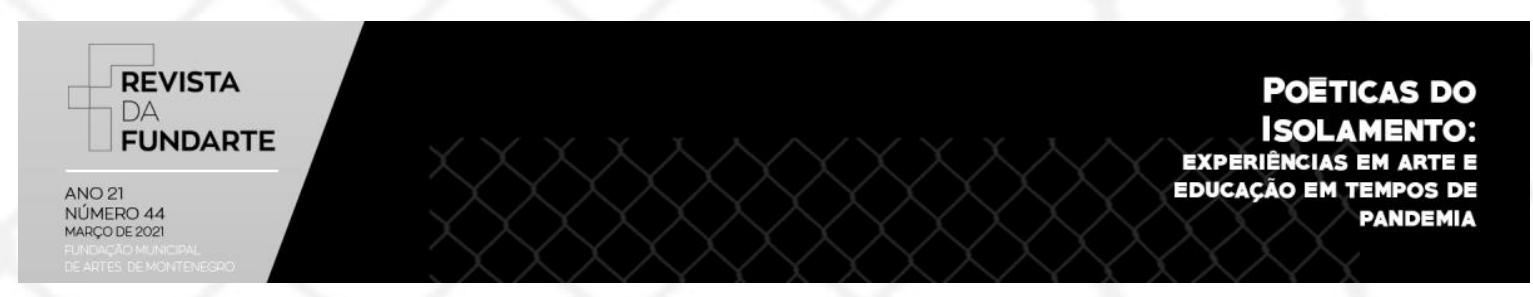

\title{
Cenário digital e a contação de histórias: (re)significa (ações) de um projeto artístico-pedagógico
}

Resumo: Esse artigo objetiva discutir e socializar os desdobramentos de um Projeto artístico-pedagógico, recorte da pesquisa de mestrado em andamento no Programa de Pós-graduação em Artes da Cena. O projeto vem sendo (re)discutido e (re)significado como prática arte-educativa de uma artista-pesquisadora-professora atuando como contadora de histórias no chão da escola e também pela internet, lugar de difusão da Arte. Assim, a produção de vídeos, lives e podcasts, mesclam a produção artística, a formação continuada e a promoção da leitura. A arte de contar histórias, eminentemente presencial, mantém seu potencial arte-educativo e a personagem revela a professora-artista, redescobrindo a contação de histórias em novos cenários.

Palavras-chave: Contação de histórias. Produção artistica. Internet.

Abstract: This article aims to discuss and socialize the developments of an artisticpedagogical project, part of the master's research in progress in the Postgraduate Program in Performing Arts. The project has been (re) discussed and (re) signified as an art-educational practice by an artist-researcher-teacher acting as a storyteller on the school floor and also on the internet, a place for the dissemination of Art. Thus, the production of videos, lives and podcasts, mix artistic production, continuing education and the promotion of reading. The art of storytelling, eminently in person, maintains its art-educational potential and the character reveals the teacher-artist, rediscovering storytelling in new settings.

Keywords: Storytelling. Artistic production. Internet.

\section{Introdução}

A prática educativa que será socializada por meio desse artigo aborda 0 projeto artístico-pedagógico "Tia Cecília conta" e alguns desdobramentos das ações que ele vem adotando no campo das práticas arte-educativas no cenário da internet sob a abordagem metodológica da Pesquisa Educacional Baseada em Arte - PEBA e a/r/tografia no desenvolvimento da pesquisa em andamento intitulada "A contação

AMORIM, Maria Cecília Silva de; FIGUEIREDO, Valéria Maria Chaves de. Cenário digital e a contação de histórias: (re)significa(ações) de um projeto artístico-pedagógico. Revista da FUNDARTE. Montenegro, p.01-20, ano 21, no 44, janeiro/março de 2021.

Disponível em: http://.seer.fundarte.rs.gov.br/index.php/revistadafundarte/index> 30 de março de 2021. 


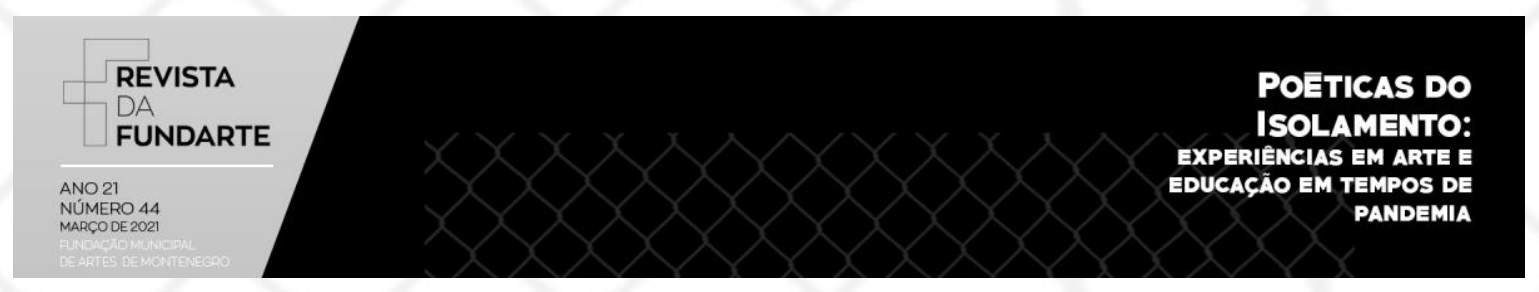

de histórias na cena: contar, encenar e (re)significar como proposição arte-educativa no chão da escola."

Apresentamos ações do "Projeto Tia Cecília conta" realizadas antes da pandemia e em sua vigência no cenário da internet trazendo outras estéticas para o objeto "contação de histórias na escola" como sinônimo da terminologia "arte de contar histórias", oriunda de tempos imemoriais ao redor de fogueiras e realizada por contadores de histórias, os quais no atual cenário de afastamento social reaparecem como cibercontadores de histórias.

O cenário educacional mundial fora alterado de maneira brusca por causa da pandemia da COVID-19, que exigiu como medidas sanitárias o afastamento social e o fechamento de escolas e universidades. As atividades de pesquisa, ensino e extensão universitárias, bem como atividades de alunos e professores em todas as modalidades de ensino, foram diretamente afetadas e as Tecnologias Digitais de Informação e Comunicação - TDICs estão sendo amplamente utilizadas para desenvolvimento de aulas remotas em atividades síncronas e assíncronas. A arte aparece no meio do caos para trazer algum alento a todos aqueles que apreciam boas histórias e as (re) significações acontecem na atuação como professora-artistapesquisadora.

\section{O Projeto e a personagem: ações e subjetividades}

O Projeto "Tia Cecília conta" foi iniciado em março de 2018 e surgiu do sonho do uso efetivo da biblioteca em uma escola de Ensino Fundamental I. Nesse período, a professora responsável pela montagem e organização da biblioteca também atuava como Coordenadora do Programa Mais Educação.

Inicialmente, o trabalho passava pela dinamização da leitura de livros literários e a realização de atividades contextualizadas a partir do momento de contação de histórias com a Tia Cecília. Após cerca de oito semanas de execução contação de histórias: (re)significa(ações) de um projeto artístico-pedagógico. Revista da FUNDARTE. Montenegro, p.01-20, ano 21, no 44, janeiro/março de 2021.

Disponível em: http://.seer.fundarte.rs.gov.br/index.php/revistadafundarte/index> 30 de março de 2021. 


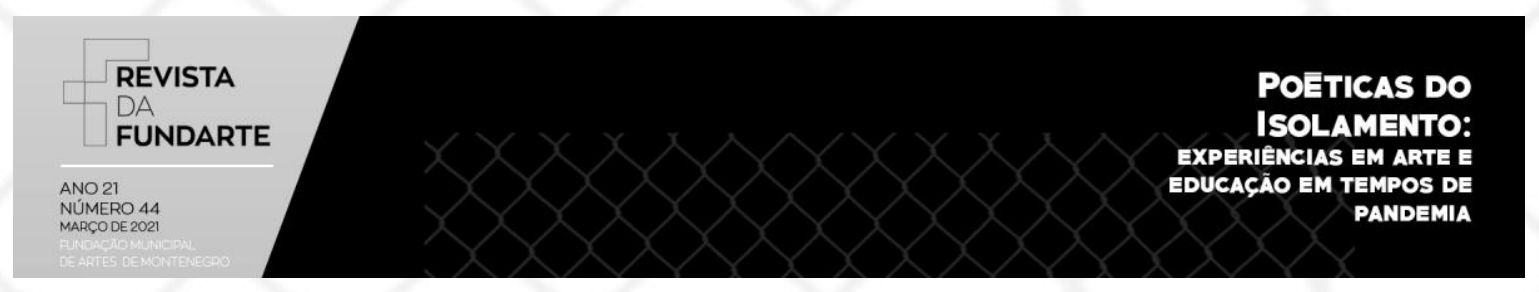

do projeto, o clima da escola estava tomado pelo encantamento dos momentos de contação de história na biblioteca, cuja dinâmica iniciava com o convite à turma e a divulgação da história da semana e, no dia e horário marcado, cada turma se reunia na biblioteca para cantar, dançar e ouvir histórias.

As histórias e a Tia Cecília se aproximaram desde a vigência do Pacto Nacional pela Alfabetização na Idade Certa - PNAIC, de 2014 a 2018, na formação de professores alfabetizadores. Por meio das histórias, além das possibilidades de melhorar o ensino e torná-lo mais dinâmico e contextualizado, veio um antigo desejo de visitar o mundo da imaginação junto com as crianças e fazer com que os momentos na escola se transformassem em uma "micro revolução literária", ajudando alunos e alunas a conhecer mais do mundo da literatura infantil, contos de tradição oral, fomentando o encantamento ao ver a professora vestida de princesa, de vovó, de caipira e até de pijama.

Nesse contexto, o projeto Tia Cecília estava sempre associado a algum conteúdo curricular, evento ou projeto buscando "interdisciplinarizar", termo ligado à Arte e usado por Ana Mae Barbosa, arte-educadora brasileira, indicando que a arte trata de interdisciplinarizar, isto é "pessoas com suas competências específicas interagem com outras pessoas de diferentes competências e criam, transcendendo cada um de seus próprios limites, ou simplesmente, estabelecem diálogos (BARBOSA e PARDO, 2012, p. 40). Sobre essa forma de unir pessoas, vale recordar que no encerramento do projeto, os alunos foram convidados a se vestirem de pijama para participar da contação, momento amplamente aceito, e houve até sessão de fotos de alunos e professores na "festa do pijama na escola".

O trabalho continuou em outra unidade escolar, agora escola de tempo integral, com o formato de oficina de literatura. A $2^{\underline{a}}$ edição possuía um espaço planejado e atendia a 19 turmas de $1^{\circ}$ ao $5^{\circ}$ ano. $O$ trabalho realizado passeava pela leitura, contação e encenação das histórias, que no momento da oficina contação de histórias: (re)significa(ações) de um projeto artístico-pedagógico. Revista da FUNDARTE. Montenegro, p.01-20, ano 21, no 44, janeiro/março de 2021.

Disponível em: http://.seer.fundarte.rs.gov.br/index.php/revistadafundarte/index> 30 de março de 2021. 


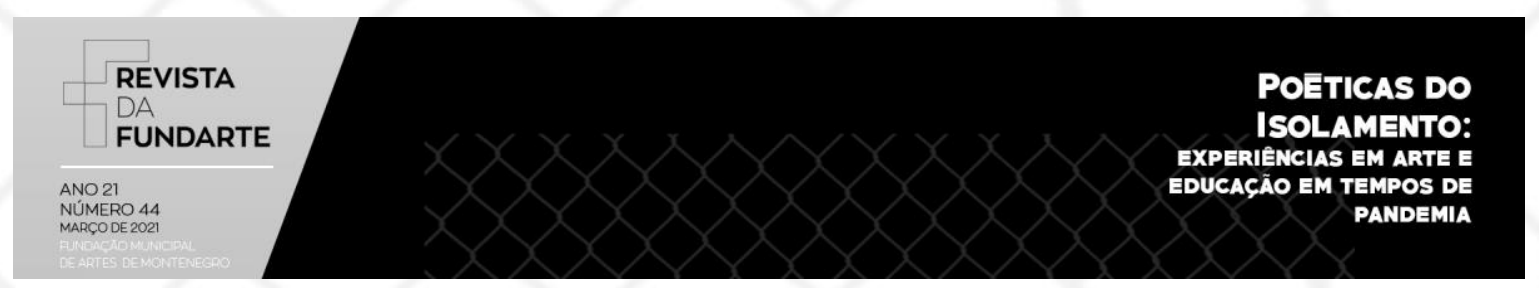

oportunizava aos alunos o contato com as linguagens da Arte: música, dança, literatura e teatro. Essa edição foi organizada para o segundo semestre de 2018.

Os alunos davam depoimentos de carinho sobre as aulas na biblioteca, dizendo até que era sua oficina preferida. Essa atitude, embora positiva, gerava questionamentos e reflexões acerca do que realmente fazia com que aquele momento fosse tão significativo para eles. Não se tratava de mediar a leitura, também não era especificamente a dinâmica de trabalho e relação com eles.

Aos poucos foi se destacando a figura da professora, daquela Tia Cecília, que se vestia diferente para a oficina. Maquiada e com vestidos de festa, alegre recebendo cada um com uma saudação de carinho à porta da entrada. Nesse sentido, a interferência da Arte no processo de ensino, de acordo com Barbosa e Pardo é positiva visto que

Arte com elemento humano agregador que, interpenetrando outras disciplinas, facilita a aprendizagem pela qualidade cognitiva dos gestos, do som, do movimento e da imagem. (...) a Arte interfere positivamente no desenvolvimento da cognição para outras áreas do conhecimento. (BARBOSA e PARDO, 2012, p. 41)

O ambiente da biblioteca, silencioso, passou a ter música e um cantinho especial para receber as histórias. Ali eram lidos livros e contadas histórias da tradição oral usando técnicas diversas. A primeira história naquele espaço como "Tia Cecília" foi "Feliz aniversário, Lua!" de Frank Asch. A técnica utilizada para apoiar a narrativa foi o teatro de sombras. A Tia Cecília recortou as silhuetas dos elementos da história: rio, urso, barco, chapéu, lua e foi colando num fundo negro à medida que a história ia se desenrolando. Os alunos pareciam hipnotizados, sentadinhos no chão da biblioteca. Foram participantes da história fazendo o barulho de eco que fazia parte do enredo.

Ali, após a contação da história discutimos sobre a narrativa e também sobre $o$ aniversário de cada um. Alguns, diziam que nunca tiveram uma festa e outros que não sabiam a data do próprio nascimento. E a proposta didática era aliada. Cada um

AMORIM, Maria Cecília Silva de; FIGUEIREDO, Valéria Maria Chaves de. Cenário digital e a contação de histórias: (re)significa(ações) de um projeto artístico-pedagógico. Revista da FUNDARTE. Montenegro, p.01-20, ano 21, no 44, janeiro/março de 2021.

Disponível em: http://.seer.fundarte.rs.gov.br/index.php/revistadafundarte/index> 30 de março de 2021. 


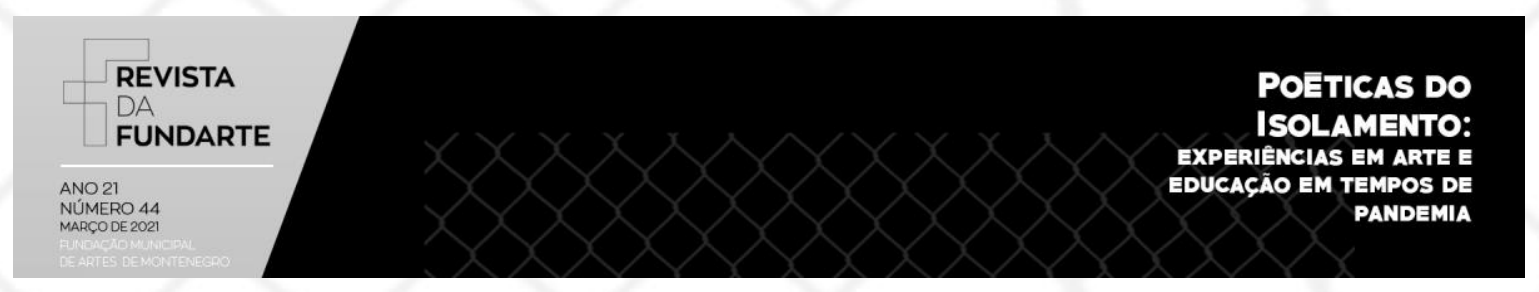

desenharia um bolo com a quantidade de velas referentes a idade e colocaria a data de aniversário. Esse movimento era feito pela Tia Cecília e os alunos ficavam à vontade para sentar-se à mesa de trabalho, lugar de exercitar a criatividade.

Todo esse trabalho ao qual nos referimos, pauta-se no campo da arteeducação. $O$ contexto educativo do projeto já caminhava para uma visão além da interdisciplinaridade, alcançando espaço de transcendência. As autoras Figueiredo e Medeiros (2019) por meio de um estudo qualitativo-descritivo procuraram elucidar práticas de ensino com características transdisciplinares. Essa concepção é apontada como um princípio epistemológico e metodológico complexo que permite que o sujeito construa um conhecimento mais global.

\begin{abstract}
$\mathrm{Na}$ medida que transcende o objeto, a disciplina, e valoriza o homem, o ser humano, o sujeito com toda a sua multidimensionalidade, enquanto alguém explora os diferentes níveis da materialidade do objeto, que utiliza sua criatividade, imaginação e intuição (...) possibilita ao indivíduo encontrar-se sempre aberto ao novo, ir além daquilo que conhece, aceitando as diferenças e sendo capaz de religar fenômenos, eventos, processos, fatos e coisas. Partindo do real para o global, a partir dos seus diferentes níveis de percepção e realidade, os quais a complexidade - enquanto fator constitutivo do real - possibilita a articulação e abertura do campo do conhecimento aos saberes não acadêmicos e ao autoconhecimento. (FIGUEIREDO e MEDEIROS In PADILHA e ABREU, 2019, p. 367-368)
\end{abstract}

Unir saber científico, saber da experiência e autoconhecimento parece uma discussão para a transdisciplinaridade. Dentre as questões levantadas: como fazer com que um projeto de contação de histórias seja pensado como fomento à arteeducação e à formação permanente e não apenas como uma ferramenta de ensino? A formação docente também necessita passar pelas paisagens das histórias (MACHADO, 2015) para exercer a docência plural com Arte e pela Arte, percebendo que o campo das narrativas possui diversas possibilidades em suportes diversos, além do livro, numa perspectiva transdisciplinar.

O cenário era a biblioteca. Os alunos também realizavam apreciação crítica de contações mediadas pelo YouTube em canais específicos como o "Varal de Histórias", cuja contadora sempre estava vestida com roupas atrativas e o canal

AMORIM, Maria Cecília Silva de; FIGUEIREDO, Valéria Maria Chaves de. Cenário digital e a contação de histórias: (re)significa(ações) de um projeto artístico-pedagógico. Revista da FUNDARTE. Montenegro, p.01-20, ano 21, no 44, janeiro/março de 2021.

Disponível em: http://.seer.fundarte.rs.gov.br/index.php/revistadafundarte/index> 30 de março de 2021. 


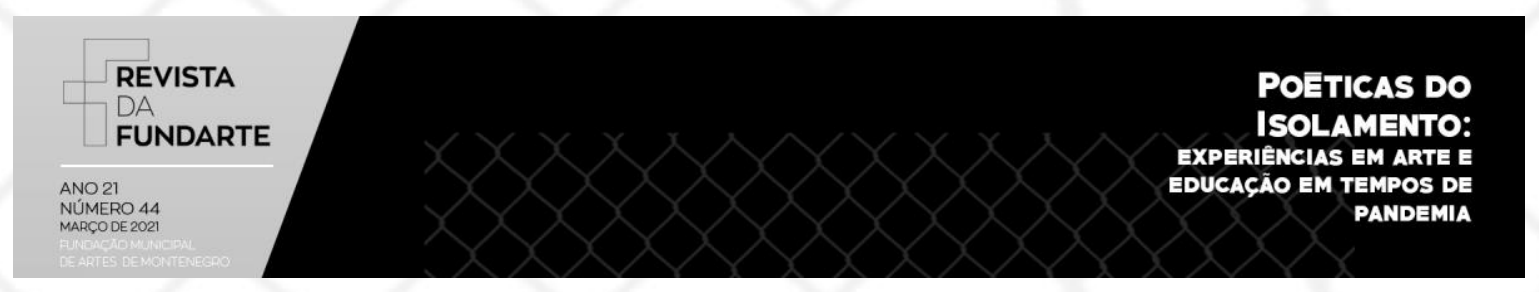

"Fafá conta histórias" cuja contadora e atriz realiza um reconto, mas mostrando o livro e sua narrativa adaptada. $\mathrm{O}$ projeto Tia Cecília conta previu o uso das tecnologias digitais por meio do YouTube e Instagram para registros dos acontecimentos artísticos do projeto. Os alunos podiam visitar os trabalhos e essa apreciação os estimulava, pois sabiam que veriam suas produções artísticas em forma de vídeo ou imagens.

No ano de 2019, para o primeiro semestre, o Projeto foi remodelado para atender literatura e teatro. Essa adequação foi feita a partir da visível adaptação dos alunos à dinâmica da oficina. A personagem da Tia Cecília ganhava traços artísticos e com o passar do tempo ia trazendo características peculiares como o uso de enfeites na cabeça, meias coloridas, um microfone de lapela com um radinho.

Outras escolas passaram a conhecer o Projeto e a convidar a personagem para realizar contações de histórias. Essa experiência foi algo bem marcante, pois, as histórias deixavam de ser vinculadas a conteúdos curriculares. O destaque se dava à performance e o manejo com o público infantil, que era motivado interagir nas histórias. O repertório para uma contação de 50 minutos era escolhido de acordo com a solicitação da escola, por exemplo quando uma professora pediu que contasse histórias para encerrar o projeto sobre alimentação saudável, as histórias que foram contadas partiam desse contexto como a "Sopa de pedras de Pedro Malasartes".

O desdobramento do projeto "Tia Cecília conta" passa pela entrada no mestrado em Artes da Cena. A professora passa a descobrir-se artista e pesquisadora numa seara dialógica, ora como artista, ora como professora. Tal possibilidade se deu ainda pela metodologia de pesquisa escolhida, a saber Pesquisa Educacional Baseada em Arte, composta pela Artografia. Esse conceito compõe ainda uma metáfora para a grafia- escrita: a- artist , $r$ - researcher e $t$ -

AMORIM, Maria Cecília Silva de; FIGUEIREDO, Valéria Maria Chaves de. Cenário digital e a contação de histórias: (re)significa(ações) de um projeto artístico-pedagógico. Revista da FUNDARTE. Montenegro, p.01-20, ano 21, no 44, janeiro/março de 2021.

Disponível em: http://.seer.fundarte.rs.gov.br/index.php/revistadafundarte/index> 30 de março de 2021. 


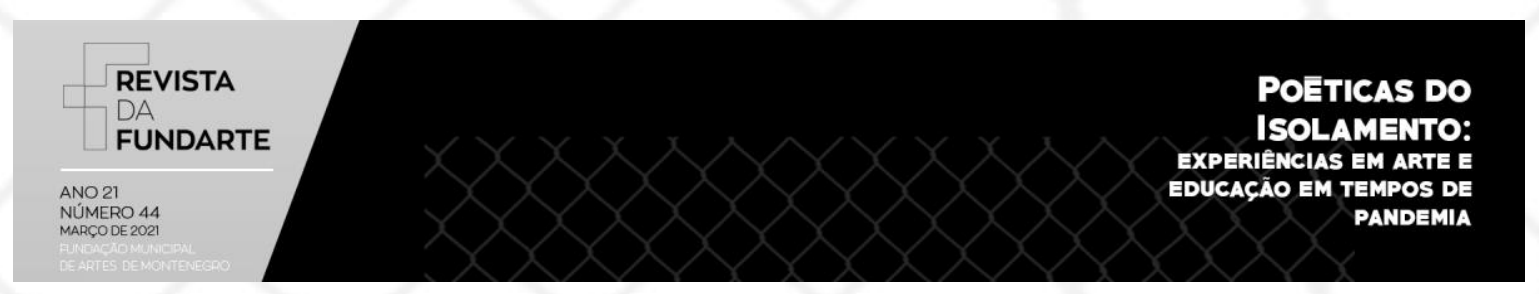

teacher. Esses termos se unem e compõe o entrelugar artista-investigador-professor caracterizando a pesquisa viva e se dá no processo de sua construção.

Para esse estudo investigativo não seria possível separar a professora em formação da artista em constituição (DIAS e IRWIN, 2013). O caleidoscópio da a/r/tografia compõe a PEBA - Pesquisa Educacional Baseada em Arte concebida em academias norte-americanas como metodologia, apoiada por artistas, arteeducadores e pesquisadores como Dias (In DIAS e IRWIN, 2013, p.24)

\begin{abstract}
PEBA oferece ao pesquisador e educador uma variedade de métodos que permitem auxiliar os processos de questionamentos, de reflexão e fazer. A/r/tografia é uma prática de PEBA e uma pedagogia instituída na Faculdade de Educação da Universidade da Columbia Britânica, UBC, Canadá que traz uma abordagem tão dinâmica à pesquisa qualitativa que essas desafiam nossas noções naturalizadas e conservadoras de se fazer educação e pesquisa. Ao colocar a criatividade à frente do processo de ensino, pesquisa e aprendizagem, a a/r/tografia gera insigths inovadores e inesperados ao incentivar novas maneiras de pensar, de engajar e de interpretar questões teóricas como um pesquisador, e práticas como um professor.
\end{abstract}

É importante compreender como entendemos subjetividades através do trabalho com a arte. Tomamos a prática da contação como uma experiência estética, a pensamos no sentido que confere John Dewey. Para Dewey (2010), a própria experiência estética não se restringe ao campo da arte, mas de fato, caracteriza-se em uma experiência no sentido de que possui contornos que the conferem uma qualidade única. Segundo Dewey, a palavra "artístico" se refere primordialmente ao ato de produção e a palavra estético, ao ato de percepção e apreciação. Para Kastrup (2008) a experiência perceptiva é, ela própria, uma experiência criadora, e completa 0 trabalho de criação. Nesse sentido, as práticas artísticas, como as experiências estéticas, acionam processos de cognição inventiva e de produção de subjetividades, engendrando domínios cognitivos e novos territórios existenciais.

AMORIM, Maria Cecília Silva de; FIGUEIREDO, Valéria Maria Chaves de. Cenário digital e a contação de histórias: (re)significa(ações) de um projeto artístico-pedagógico. Revista da FUNDARTE. Montenegro, p.01-20, ano 21, no 44, janeiro/março de 2021.

Disponível em: http://.seer.fundarte.rs.gov.br/index.php/revistadafundarte/index> 30 de março de 2021. 


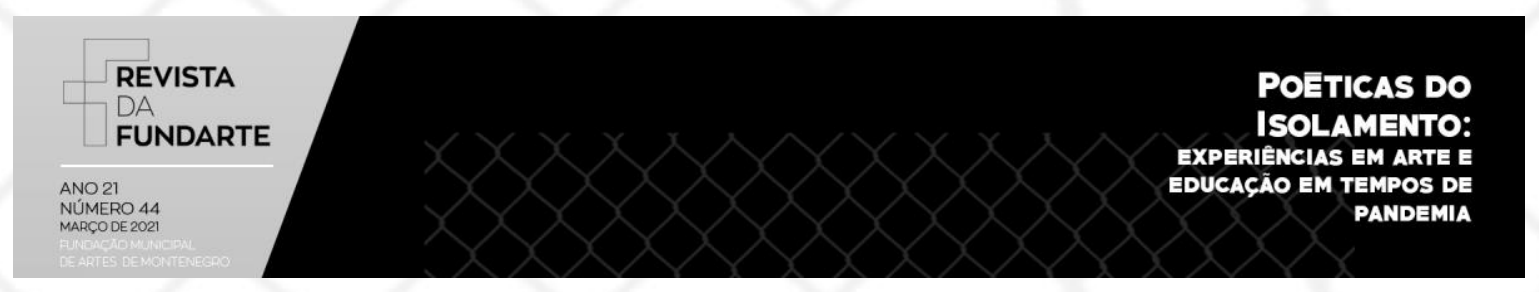

O contar histórias no chão da escola configura uma ação presencial, necessita de público e por isso, fez-se necessário continuar o projeto, porém no contexto da internet com as (re) significações necessárias e possíveis para manter as aprendizagens. Esse movimento se deu por causa da pandemia de Covid-19, que desde março de 2020 fez com que alunos e professores e escolas de muitos lugares em todo mundo realizassem formas alternativas de ensino e os artistas contadores de histórias iniciaram o movimento ativo de Arte pelas Redes.

\title{
2. A Arte de contar histórias e a tecnologia digital: Cibercontadores
}

A arte se faz cada vez mais presente por meio da internet e, assim como Busatto (2013) pensava sobre a própria constituição enquanto contadora e se colocava como personagem, pensamos a contação de histórias a partir deste mesmo ponto de vista, salientando que

\begin{abstract}
...enquanto os contos aguardam a voz que os tornará reais, uma personagem elabora reflexões sobre a arte de contar histórias, e se enrola nas teias do tempo, ora se vendo no incunábulo desta tradição, misturada a bardos e griots, sherazades e avós; ora se vendo num tempo futuro, disputando o espaço com a imediatez e a instantaneidade do ciberespaço, tentando andar de braço dado com a era da informática, ao se lançar como uma cibercontadora. (BUSATTO, 2013, p.09)
\end{abstract}

A poética da contação de histórias, arte do encontro e da presença, se relaciona às práticas educativas também no contexto de pandemia do Covid-19 que alcançou a população brasileira em março de 2020. A arte e suas linguagens aparecem como elementos fundamentais para que as pessoas consigam se estabilizar no momento de crise, pois a necessidade de afastamento social fechou escolas e lugares onde a contaminação é mais possível pela aglomeração de pessoas.

A internet e seus canais trouxeram pelas redes algumas possibilidades de reuniões remotas, educação à distância e para as crianças a produção de conteúdos tornou-se muito mais necessária e assim como ocupações que atuam com o ensino,

AMORIM, Maria Cecília Silva de; FIGUEIREDO, Valéria Maria Chaves de. Cenário digital e a contação de histórias: (re)significa(ações) de um projeto artístico-pedagógico. Revista da FUNDARTE. Montenegro, p.01-20, ano 21, no 44, janeiro/março de 2021.

Disponível em: http://.seer.fundarte.rs.gov.br/index.php/revistadafundarte/index> 30 de março de 2021. 


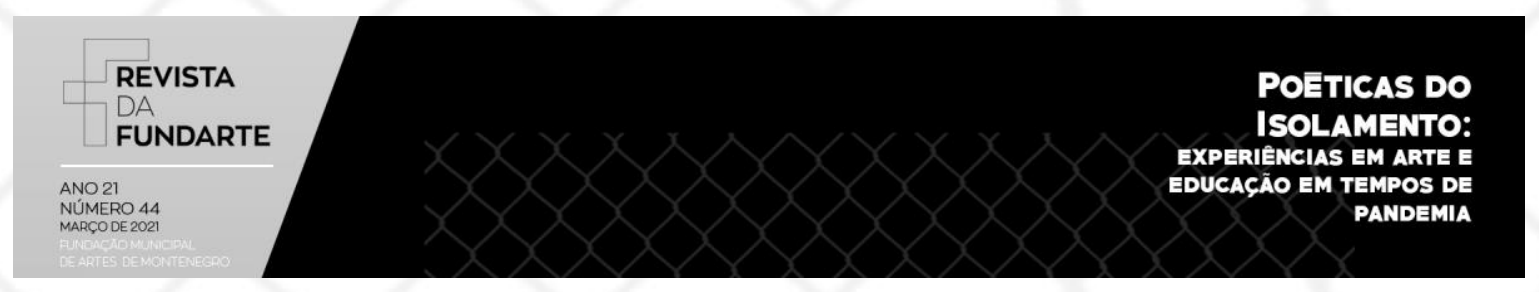

o contador de histórias contemporâneo teve que se reinventar nesse processo. A arte de contar histórias, provavelmente a primeira desenvolvida pelo homem, surge como espaço de promoção de equilíbrio e diálogo no espaço virtual.

Desvendar o campo da arte, pensando em como produzir conhecimento como ciência, aponta para a discussão sobre semiótica, abordagem realizada por Santaella (2012) que realiza um estudo da historicidade das tecnologias no cotidiano das pessoas e traz marcos importantes para a nova perspectiva do que a arte passou a representar no pós-renascimento.

A autora utiliza os termos "floresta de signos" e "floresta de tempo" para se referir às mudanças relacionadas às linguagens artísticas como metáfora no presente, passado e futuro. Se antes o contador de histórias, griot, como chamado na África, tinha apenas sua voz e sua imagem corporal para emprestar aos personagens, com a tecnologia pode amplificar sua voz, ter a sua disposição diversos sons em um pen drive e usar ou não outros adereços... luz, câmera e ação! Assim,

a eletromecânica, a eletrônica e a digital (...) na terceira as relações entre arte e ciência passaram a ser mediadas pelos aparatos tecnológicos. Uma vez descobertos pela ciência, esses aparatos passam a ser imediatamente apropriados pelos artistas para a exploração dos novos potenciais que eles abrem para a criação artística. (SANTAELLA, 2012 In RAMOS, p.62)

Existe uma relação híbrida entre arte, ciência e tecnologia. Diante desse hibridismo "o artista não se coloca simplesmente na posição daquele que faz uso dos resultados de pesquisas realizadas pelos cientistas, mas participa ele mesmo na atividade da pesquisa." (SANTAELLA, 2012 In RAMOS, p. 67)

A discussão sobre o contador de histórias e a tecnologia faz parte do trabalho de pesquisa de Schermack (2013, p.03) reiterando que "o suporte digital constitui-se num recurso para a contação de histórias em tempo de Cibercultura, para confirmar a importância da figura do contador de histórias, o qual se apropria de recursos

AMORIM, Maria Cecília Silva de; FIGUEIREDO, Valéria Maria Chaves de. Cenário digital e a contação de histórias: (re)significa(ações) de um projeto artístico-pedagógico. Revista da FUNDARTE. Montenegro, p.01-20, ano 21, no 44, janeiro/março de 2021.

Disponível em: http://.seer.fundarte.rs.gov.br/index.php/revistadafundarte/index> 30 de março de 2021. 


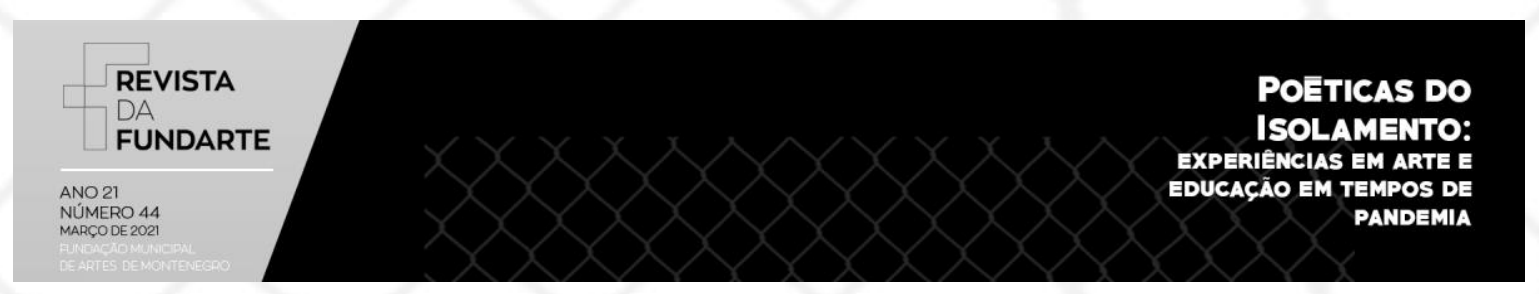

tecnológicos com vistas à formação de múltiplos leitores." Sem a intenção de provocar antagonismos surge a necessidade de pensar sobre o contador de histórias tradicional e contemporâneo, que mesmo possuindo uma atividade circunstancialmente presencial precisou se adaptar ao cenário de Arte e produção de contações pela internet. $O$ conceito de Cibercultura é desenvolvido por Pierre Lévy como "o conjunto de técnicas (materiais e intelectuais), de práticas, de atitudes, de modos de pensamento e de valores que se desenvolvem juntamente com o ciberespaço." (LÉVY apud SCHERMACK, 2013, p. 11)

Frente ao desenvolvimento das tecnologias digitais de informação e comunicação - TDICs e as redes sociais, as contações de histórias têm sido utilizadas para promover a arte de contar histórias e atender à organização do caos emocional instaurado entre as famílias. Trazendo a percepção de Walter Benjamim, crítico da literatura que em 1927 discutia o papel do narrador, o qual naquela época havia dado quase como extinto, cabe questionar: o caos da pandemia fez ressurgir a figura do contador de histórias?

A arte de narrar atravessa ainda as dificuldades de formação para o uso da tecnologia digital e aparece transposta para a era digital amplamente lúdica e reflexiva, manifestada em vídeos, lives com a união de contadores de diversos lugares em plataformas de comunicação como o WhatsApp, Facebook e Instagram mediados por elementos cênicos-digitais, e pode-se destacar que

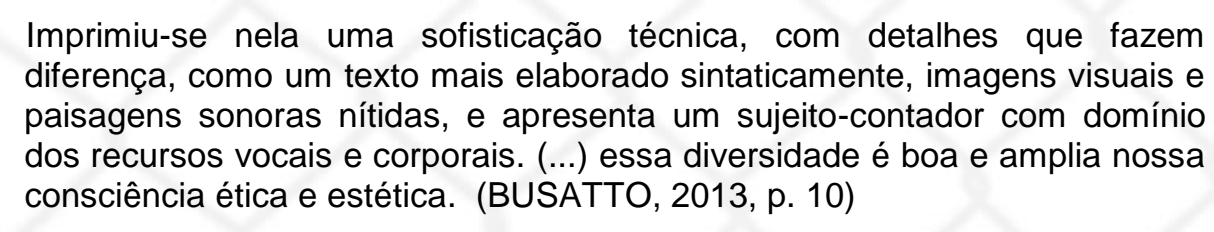

A utilização das redes para contar histórias não substitui o contato com o público, pelo contrário, o uso das redes aparece como contexto novo e de aprendizados importantes para manter viva a arte de contar. A performance do contador de histórias pelas redes sofreu adaptações pela necessidade de continuar

AMORIM, Maria Cecília Silva de; FIGUEIREDO, Valéria Maria Chaves de. Cenário digital e a contação de histórias: (re)significa(ações) de um projeto artístico-pedagógico. Revista da FUNDARTE. Montenegro, p.01-20, ano 21, no 44, janeiro/março de 2021.

Disponível em: http://.seer.fundarte.rs.gov.br/index.php/revistadafundarte/index> 30 de março de 2021. 


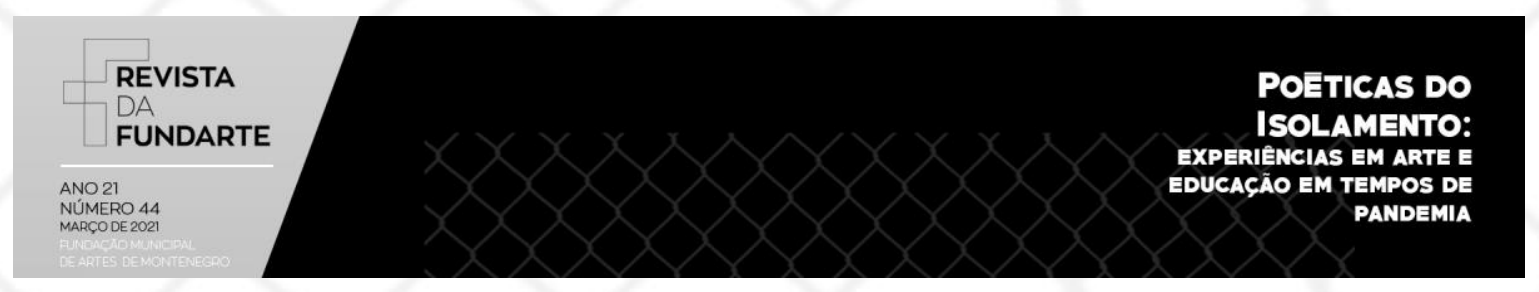

existindo e se fortalecendo. A concepção de performance que adotamos é utilizada por Matos (2014) a partir do estudo de Paul Zumthor e a apresenta como "ação complexa" que envolve o tripé contador, ouvinte e espaço/tempo/circunstância. Trazendo para a realidade na qual estamos atuando, essa performance tomou espaço na comunicação móvel. "Além da singularidade de sua palavra, a poética dos contadores de histórias - própria do estilo oral - é constituída pela performance que, ao mesmo tempo é um elemento, é também o principal fator constitutivo dessa poética." (MATOS, 2014, p. 53)

O chão da escola seria o lugar de pesquisa e de realização de uma proposição arte-educativa, porém interrompida/adiada pela pandemia, deu lugar a novas formas de produção artística fortalecendo a presença e o processo artístico para atuar mediada pelas redes. Assim, o caos deu lugar às novas experiências e criações, encontros virtuais e aprendizagens sensibilizadoras anteriores à pesquisa de campo.

\section{Processo artístico: contações em plataformas da internet}

A tecnologia digital e suas diversas propostas aliadas ao uso de aparatos não é suficiente sem formação adequada e sem um contexto para sua aplicação. Desse modo, uma atividade que é presencial como a contação de histórias passou por rápidas adaptações, uma vez que "a tecnologia, especialmente os dispositivos móveis e a internet, está influenciando diversos aspectos da vida em sociedade, em outras palavras, práticas sociais de diferentes naturezas 0 que inclui práticas discursivas e educacionais." (RIBEIRO e VILAÇA In VILLAÇA e ARAÚJO, p. 19, 2016)

Nesse sentido, o desdobramento do projeto abraça ações mediadas pela internet que a cada dia impulsionam diferentes práticas sociais, o que tem reflexos na Arte-Educação. As relações entre alunos e professores tomaram outra contação de histórias: (re)significa(ações) de um projeto artístico-pedagógico. Revista da FUNDARTE. Montenegro, p.01-20, ano 21, no 44, janeiro/março de 2021.

Disponível em: http://.seer.fundarte.rs.gov.br/index.php/revistadafundarte/index> 30 de março de 2021. 


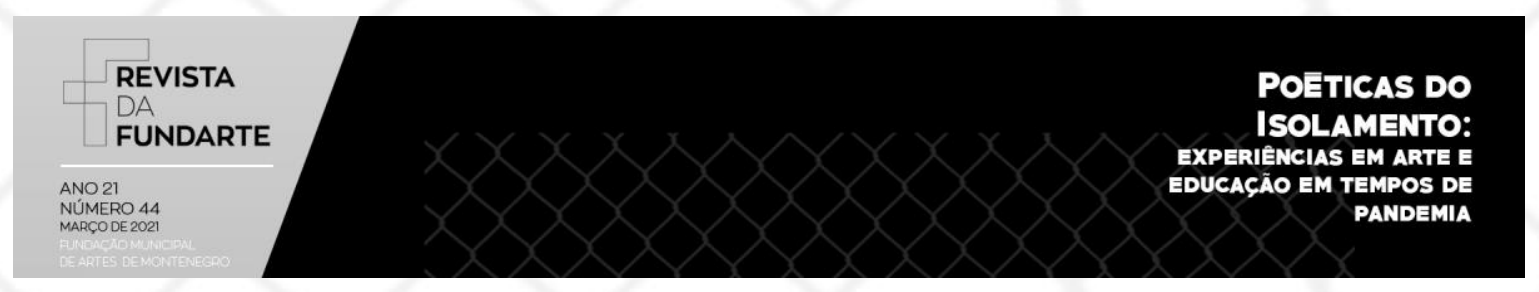

configuração assim como a sala de aula, que agora têm funcionado por meio do ensino remoto. A escola passou a adotar outras maneiras de ensinar e o trabalho educativo pelas redes em parceria com as famílias foi instaurado. E o Projeto que seria pesquisa de campo de abril a agosto de 2020, adotou novas possibilidades, entre elas a da Cibercontação termo utilizado por Busatto (2013) para nomear o momento de contar histórias mediado pela internet. Assim, algumas ações têm sido realizadas para adequar o Projeto Tia Cecília conta ao contexto de isolamento social buscando grupos de contadores de histórias e cursos para ampliar a visão a partir da cibercontação.

A busca por grupos de contadores deu a conhecer a Rede Brasil Histórias de Todos os Cantos, idealizada pela contadora de histórias sergipana, Fátima Colares. Essa participação vem acontecendo via grupo de WhatsApp desde março. A Rede tem por objetivo unir contadores de todo o Brasil por meio da arte de contar histórias, vislumbrando compartilhar conhecimentos e experiências. Atualmente, o grupo conta com média de 240 membros de diversos lugares do país. Desde o dia 20 de março de 2020, dia do contador de histórias, a Rede propõe ações individuais e coletivas para integrar contadores pela internet e mobilizar novas práticas artísticas.

A entrada e integração no grupo foi o início de um novo percurso de formação, o qual passamos a chamar de "bagagem do viajante", metáfora que ilustra a busca de conhecimento e as diversas passagens que nos formam e constituem permanentemente.

Enquanto a pesquisa de campo e a incerteza dos tempos pandêmicos em voga, instaurou-se um tempo de aprender mais sobre arte e a performance enquanto contadora de histórias e a produção criativa de vídeos-contação. Momentos formativos foram motivadores para produções de vídeos-contação como a participação na oficina de contadores online da \#ocupafeteg e Teatro Destinatário. contação de histórias: (re)significa(ações) de um projeto artístico-pedagógico. Revista da FUNDARTE. Montenegro, p.01-20, ano 21, no 44, janeiro/março de 2021.

Disponível em: http://.seer.fundarte.rs.gov.br/index.php/revistadafundarte/index> 30 de março de 2021. 


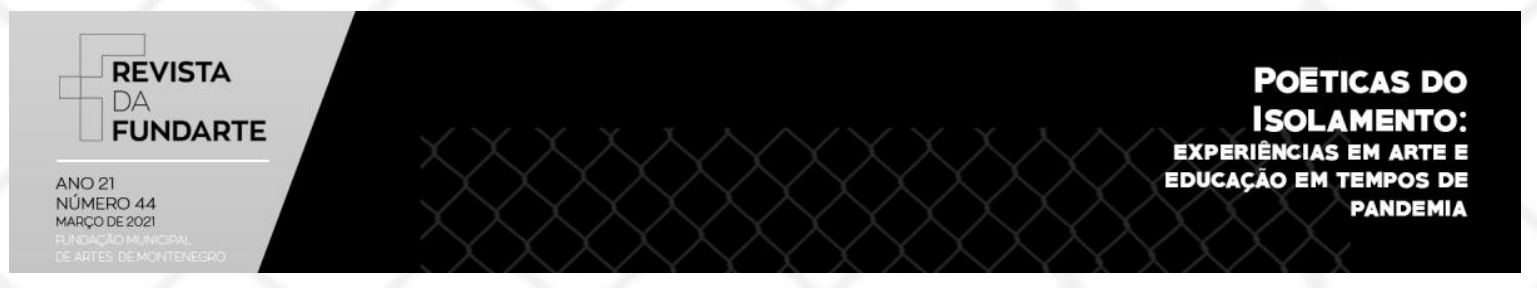

Por meio do encontro com outros contadores de forma virtual, a intenção era de aprender, compartilhar e desenvolver processos artísticos por meio de ações formativas mediadas por lives pelo YouTube, Facebook e Instagram em busca de (re) significar o processo de pesquisa em arte.

\subsection{Produção e participação em lives}

A primeira participação da personagem Tia Cecília em live (ao vivo) aconteceu no mês de maio na ação \#UnidosPelaHistória proposta pela Rede Brasil Histórias de Todos os Cantos. Dentre as diversas propostas mensais do grupo, estava convidar alguém para contar histórias em parceria.

O convite foi lançado para o grupo aleatoriamente e aceito por quatro contadoras: Raquel de Itumbiara -GO, Sirlei de Araquari -SC, Ana Selma Cunha -PA e Elite Landim de Cariacica- ES. A live "Unidas pela história" foi exibida no YouTube no dia 28 de maio e já alcançou mais de 600 acessos. O conteúdo da live foi dividido em três momentos: apresentação das contadoras, história coletiva e bate-papo formativo sobre a importância das histórias no período de pandemia.

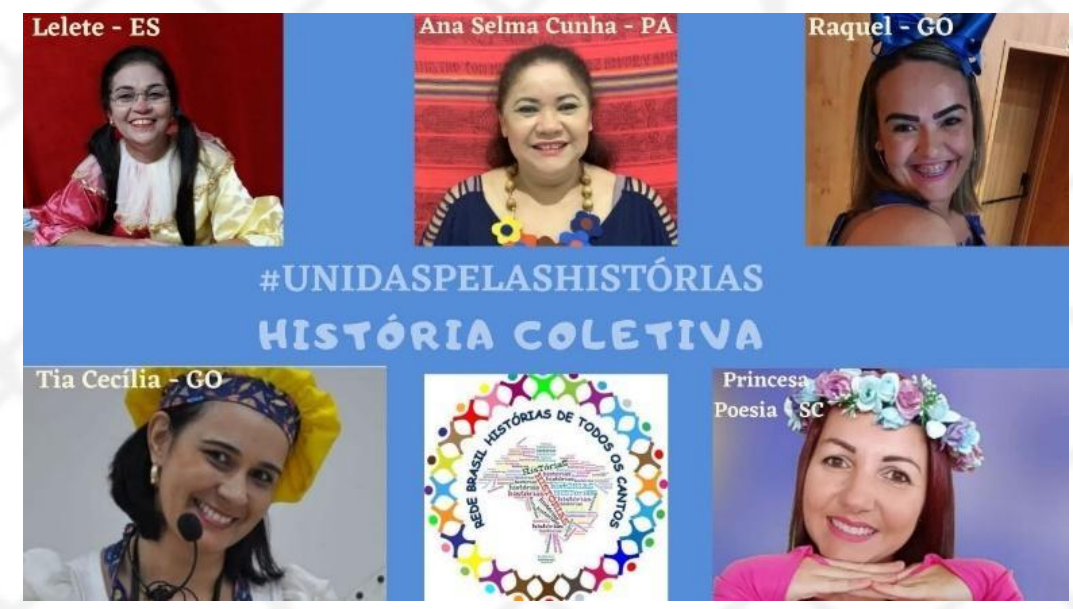

Figura 1. Cartaz da Live Unidas pelas histórias, com apoio da Rede de contadores de histórias, disponível em https://youtu.be/mqYXYBsHSUg, 2020. contação de histórias: (re)significa(ações) de um projeto artístico-pedagógico. Revista da FUNDARTE. Montenegro, p.01-20, ano 21, no 44, janeiro/março de 2021.

Disponível em: http://.seer.fundarte.rs.gov.br/index.php/revistadafundarte/index> 30 de março de 2021. 


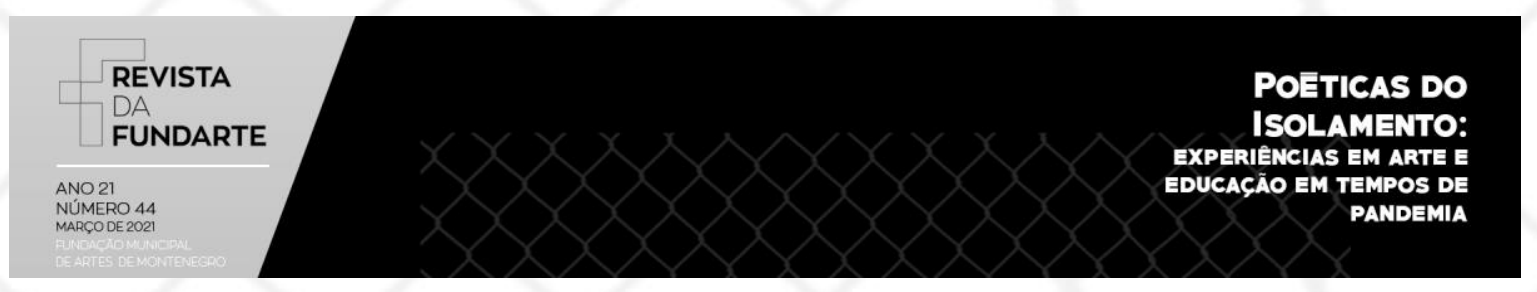

Esse encontro gerou forte laço de amizade e admiração do trabalho de cada uma. A história coletiva foi planejada, traçada em forma de roteiro, ensaiada. A fábula do "Vestido azul" veio para nos fortalecer como artistas-educadoras e motivar ações de intervenção pelas redes. Após essa live várias outras aconteceram, mas certamente essa foi a chave que destrancou a porta da dificuldade de expressão mediada pela internet, uma verdadeira quebra de paradigma, necessária para novos rumos e experimentações.

\subsection{Produção de vídeos}

A produção de vídeos para o canal do Youtube foi motivada especialmente pela participação na Oficina Online de Contação de Histórias promovida pela \#OcupaFeteg - Federação de Teatro Goiana no mês de abril. Os vídeos estão com acesso público e a produção do processo criativo passou pela experiência narrativa da professora-artista.

Os vídeos produzidos na oficina foram "O caso do Bolinho", texto adaptado a partir de Tatiana Belink e o segundo, um vídeo considerando a história de vida da dona Creusa e seu noivado com Galdino. Ambos foram produzidos no cenário doméstico e editados em aplicativos no smartphone. O vídeo sobre a história de Dona Creusa foi o mais significativo, pois ainda não havia tido a experiência com um reconto de história de vida.

A opção foi o cenário da janela, do cotidiano, recordando que as mulheres geralmente enquanto contam histórias e cantam vão cuidando dos afazeres domésticos. Alcançar a memória dos tempos em que ela viveu e o jeito que era influenciou diretamente a performance. Na figura 1, Dona Creusa com sua netinha ao colo em frente à Igreja do Rosário, local histórico da cidade.

AMORIM, Maria Cecília Silva de; FIGUEIREDO, Valéria Maria Chaves de. Cenário digital e a contação de histórias: (re)significa(ações) de um projeto artístico-pedagógico. Revista da FUNDARTE. Montenegro, p.01-20, ano 21, no 44, janeiro/março de 2021.

Disponível em: http://.seer.fundarte.rs.gov.br/index.php/revistadafundarte/index> 30 de março de 2021. 

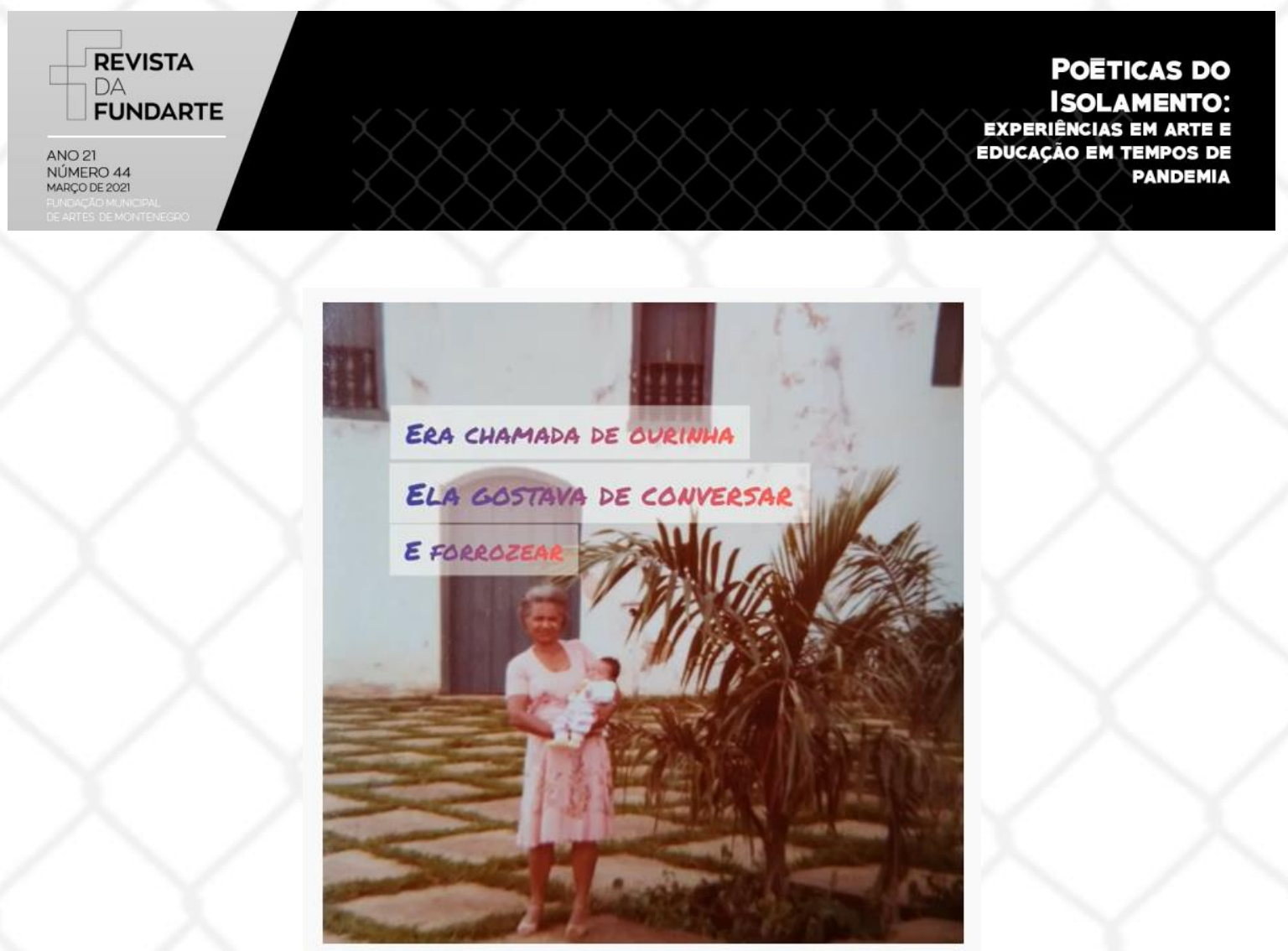

Figura 2. Interface da vídeo-contação "O noivado de Dona Creusa", disponível em https://youtu.be/czlgZ6upRig, 2020.

Também foi produzido um vídeo para apoiar o Projeto "Reinventando a sala de Aula", no canal do YouTube "Cafubira Literária", organizado pela escritora-artistaprofessora goiana Dani de Brito. O vídeo procura, em seus 10 minutos de duração, motivar os professores a contar histórias pela internet aos seus alunos e apresenta alguns elementos que favorecem essa possibilidade, como o uso de aplicativos de para edição de vídeos e elementos cênicos: livros, objetos e outros.

Nessa produção, além dos elementos cênicos houve a experimentação do Chroma Key, que consiste na utilização de um pano verde-limão ao fundo na gravação, que irá ser absorvido por imagens sobrepostas na edição do vídeo, técnica muito usada para a edição, uma vez que os cenários podem ser facilmente adaptados.

A exploração de recursos de imagem em busca de um refinamento técnico e estético para os vídeos acolheu uma solicitação da Secretaria Municipal de Educação, especialmente pela Educação Infantil. Foi produzida uma vídeo-contação contação de histórias: (re)significa(ações) de um projeto artístico-pedagógico. Revista da FUNDARTE. Montenegro, p.01-20, ano 21, no 44, janeiro/março de 2021.

Disponível em: http://.seer.fundarte.rs.gov.br/index.php/revistadafundarte/index> 30 de março de 2021. 


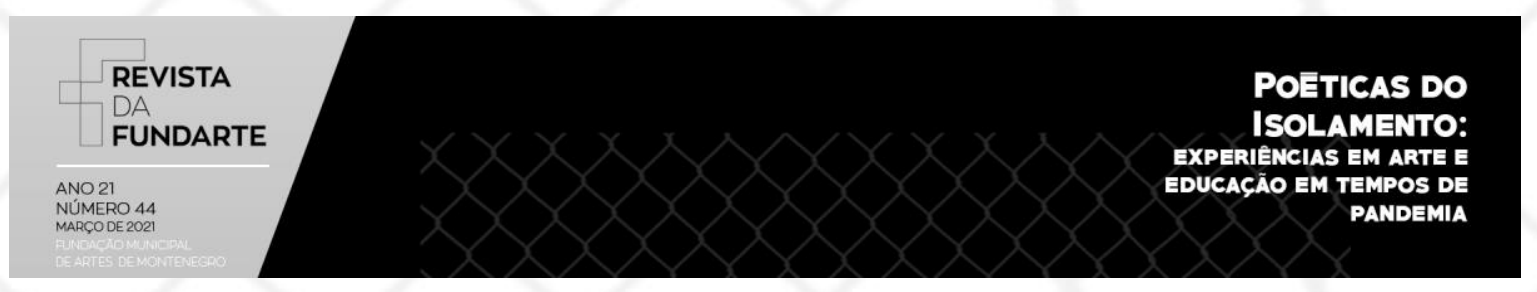

da história clássica "O patinho feio", a qual serviu como recurso para mais de 4000 alunos e professores. A experiência artística dessa produção alcançou a professoraartista que em sua performance cantou e narrou a história lançando mão de imagens e sons, numa edição usando vários aplicativos. A figura 3 apresenta a interface do vídeo postado no YouTube.

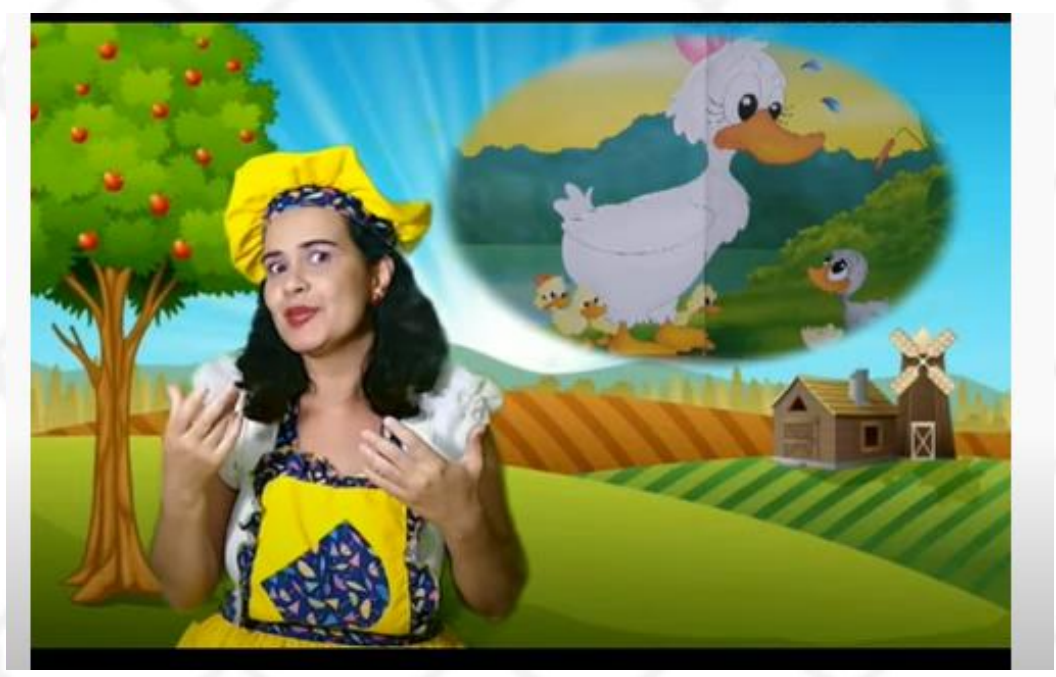

Figura 3. Interface da vídeo-contação "O patinho feio", disponível em https://youtu.be/lo9SKOBMqMA , 2020.

\subsection{Produção de podcasts}

Outro formato virtual que vale ser citado é a produção de histórias em áudio. A Plataforma Anchor - aplicativo para smartphone - foi utilizada para realizar gravações de podcasts/áudios de algumas histórias vinculadas a atividades de ensino para alunos de $4^{\circ}$ e $5^{\circ}$ ano. $O$ aplicativo cuja interface é intuitiva propicia uma produção artística fácil e a arte final é uma produção automática.

O conteúdo fora desenvolvido em maio e objetivou exercitar a narração de histórias e estimular a leitura de alunos na Rede Municipal de Ensino. As professoras indicavam o link para os alunos que puderam ter contato com as obras via áudio variando de 46 segundos a 9 minutos de duração. Diante da expansão e contação de histórias: (re)significa(ações) de um projeto artístico-pedagógico. Revista da FUNDARTE. Montenegro, p.01-20, ano 21, no 44, janeiro/março de 2021.

Disponível em: http://.seer.fundarte.rs.gov.br/index.php/revistadafundarte/index> 30 de março de 2021. 


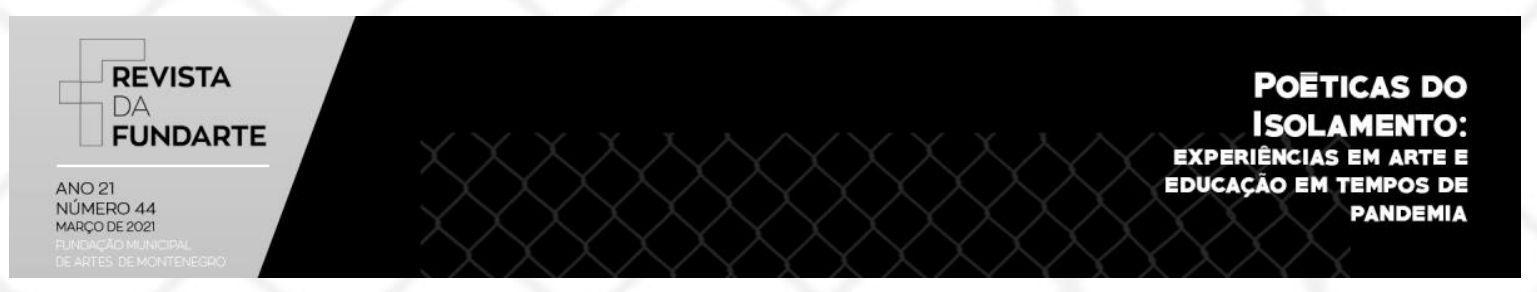

do uso das histórias de autoria, houve um cuidado com as questões relacionadas aos direitos autorais.

O podcast do livro "Camilão, O comilão" de Ana Maria Machado, estimulou o trabalho pedagógico de uma Professora de $4^{\circ}$ ano, que usando o material em áudio propôs aos alunos uma atividade interpretativa pelo Google Forms relacionando questões sobre cidadania, empatia e consumismo.

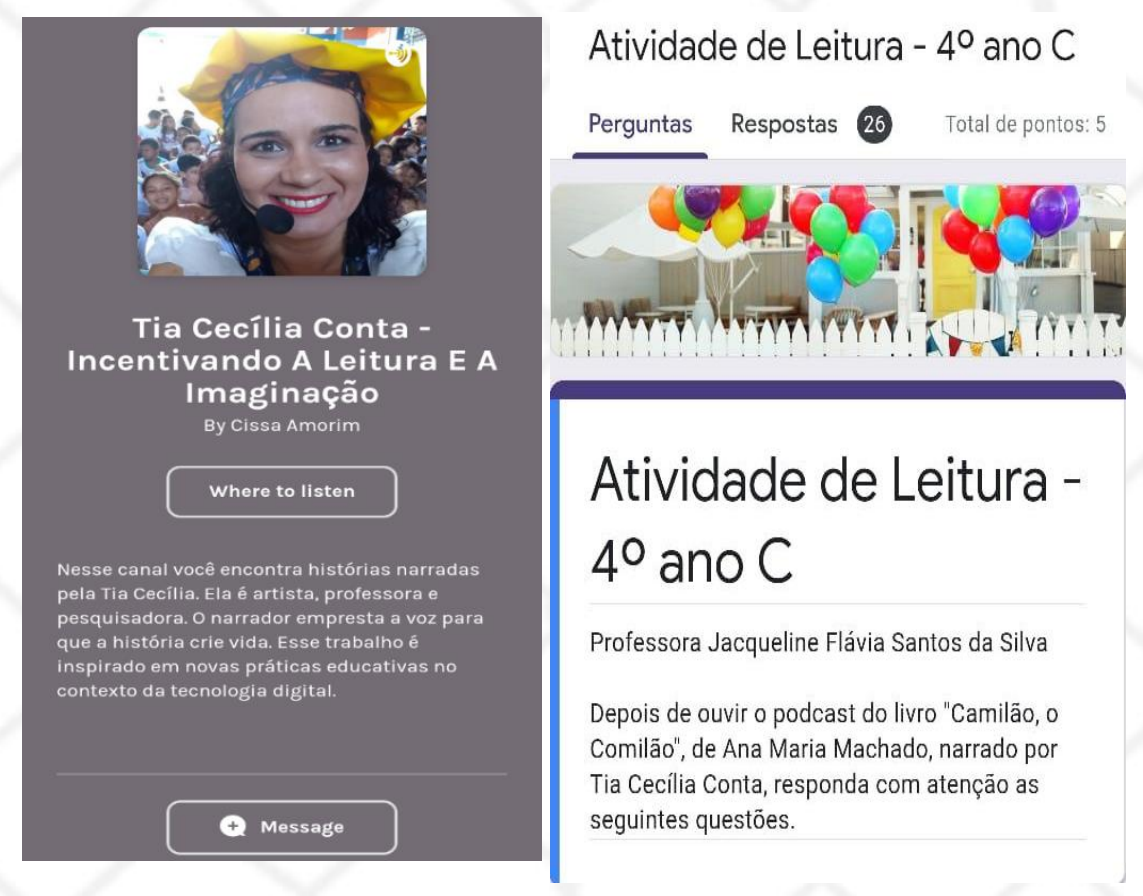

Figura 4. Interface do canal Podcast - Anchor e atividade Google Forms

A produção artística aliada ao ensino foi um contexto favorável de produções significativas que antes não haviam sido experienciadas. Apesar da pandemia ter tirado oportunidades de presença física, houve uma expansão no campo da arteeducação pelas redes sociais. A produção de lives, vídeos-contação e podcasts oportunizou o contato com uma poética híbrida que possibilitou novas aprendizagens para a professora-artista-pesquisadora que no fazer artográfico tem apreendido sobre arte-educação e tecnologia digital. Essa (re) significação fora contação de histórias: (re)significa(ações) de um projeto artístico-pedagógico. Revista da FUNDARTE. Montenegro, p.01-20, ano 21, no 44, janeiro/março de 2021.

Disponível em: http://.seer.fundarte.rs.gov.br/index.php/revistadafundarte/index> 30 de março de 2021. 


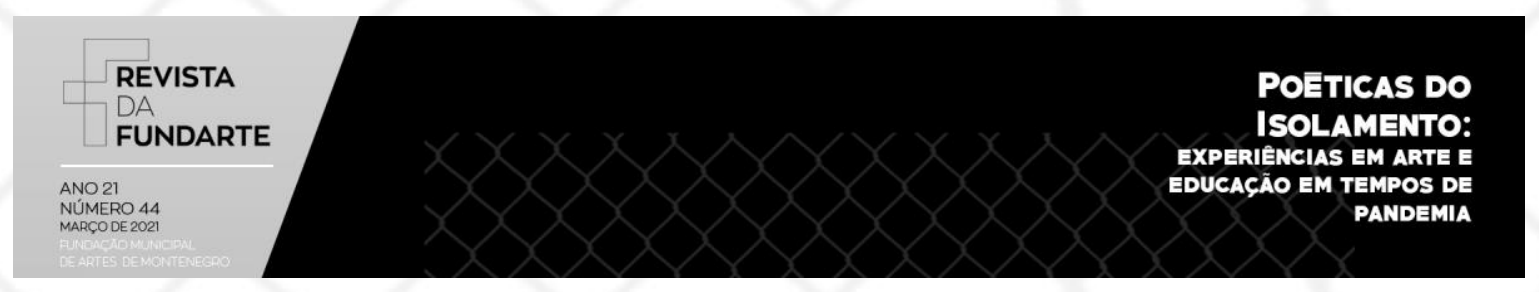

fundamental para acolher a estética de uma performance sem público presente lidando com outros tipos de interação frente ao meio digital em tempos de pandemia.

\section{Considerações}

A reflexão sobre o Projeto "Tia Cecília conta" e a (re) significação da docência-artística na criação e constituição de uma personagem, perpassa por algumas questões importantes descritas e socializadas nesse trabalho, como a de entrar em contato com outros artistas, especialmente, contadores de história para compreender pela experiência de outros essa arte milenar, no momento transposta por cibercontadores em diferentes plataformas como WhatsApp, YouTube, Instagram, Facebook, Anchor, possibilitando novas relações sociais, artísticas e educativas mediadas pela tecnologia digital. Esses elementos atravessaram a pesquisa em andamento e foram absorvidas por ela para contextualizar produções em tempos de pandemia.

O caráter do projeto, que embora pensado no contexto da escola, do ensino para crianças, pode ser desenvolvido coletivamente e buscando atender às necessidades vinculadas à arte-educação no cenário da internet.

Percebe-se que é possível produzir conhecimento com base na experiência como artista-professora-pesquisadora unindo saber da experiência e saber científico de forma significativa, considerando que a interdisciplinaridade já não mais abarca o Projeto "Tia Cecília conta" possivelmente por suas características de reconhecimento do sujeito e de seus contextos ampliados. A reflexão poderá adotar a epistemologia da transdisciplinaridade sob a qual o paradigma que se apresenta é o das mudanças que as relações entre os sujeitos provocam nas aprendizagens.

Por meio das produções realizadas no campo da tecnologia digital como lives, vídeos e podcasts, pode-se perceber que as ações de produção de conteúdo artístico vinculadas à contação de histórias têm sido buscadas por professores, contação de histórias: (re)significa(ações) de um projeto artístico-pedagógico. Revista da FUNDARTE. Montenegro, p.01-20, ano 21, no 44, janeiro/março de 2021.

Disponível em: http://.seer.fundarte.rs.gov.br/index.php/revistadafundarte/index> 30 de março de 2021. 


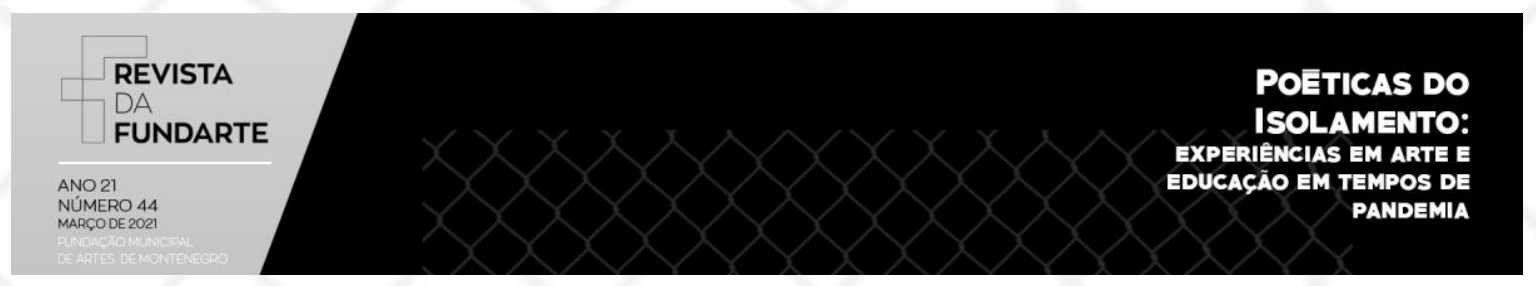

alunos e contadores de histórias que se ligaram a partir da pandemia de Covid-19 especialmente pelo WhatsApp, especialmente pela Rede Brasil Histórias de Todos os Cantos.

A perspectiva da produção educativa pela Arte com base na ação-reflexãoação, postulada por Freire (1996) remonta a (re)significação da experiência de uma artista-professora-pesquisadora a trilhar caminhos de transdisciplinaridade em conexão com a tecnologia digital e o ensino no cenário da internet, vislumbrando a produção de conteúdo digital de qualidade, disponibilizado em plataformas da internet com a sensibilidade de artista e o olhar de professora para uma nova maneira de ensinar pelas redes.

\section{Referências}

BARBOSA, A. M.; PARDO, M. F. Arte na educação: interterritorialidade, interdisciplinaridade e outros inter. Visualidades, v. 3, n. 1, 10 abr. 2012. Disponível em: https://www.revistas.ufg.br/VISUAL/article/view/17929 Acesso em: 30 jun. 2020.

Benjamim, W. O Narrador. In: Benjamim, W. Magia e técnica, arte e política. São Paulo: Editora Brasiliense, 1987.

BUSATTO, C. A arte de contar histórias no século XXI: Tradição e ciberespaço. 4.ed. Petrópolis, RJ: Vozes, 2013.

DEWEY, J. A arte como experiência. Trad. Vera Ribeiro. São Paulo: Martins Fontes, 2010.

DIAS, B. A/r/tografia como metodologia e pedagogia em Artes: uma introdução. In: DIAS, B. e IRWIN, R. L. (Orgs.). Pesquisa Educacional Baseada em arte: a/r/tografia. Santa Maria: Ed. da UFMS, 2013.

FIGUEIREDO, V.M.C. e PARDO, T.M.S. Arte sob a ótica da transdisciplinaridade: lugar de descobertas, reinvenções e interações. In: PADILHA, P. R. e ABREU, J. (Orgs). Paulo Freire em tempos de fake news [livro eletrônico]: artigos e projetos de intervenção produzidos durante o curso da EaD Freiriana do Instituto Paulo Freire. São Paulo: Instituto Paulo Freire, 2019.

FREIRE, P. Pedagogia da autonomia: saberes necessários à prática educativa. 52. ed. São Paulo: Paz e Terra, 2015. contação de histórias: (re)significa(ações) de um projeto artístico-pedagógico. Revista da FUNDARTE. Montenegro, p.01-20, ano 21, no 44, janeiro/março de 2021.

Disponível em: http://.seer.fundarte.rs.gov.br/index.php/revistadafundarte/index> 30 de março de 2021. 


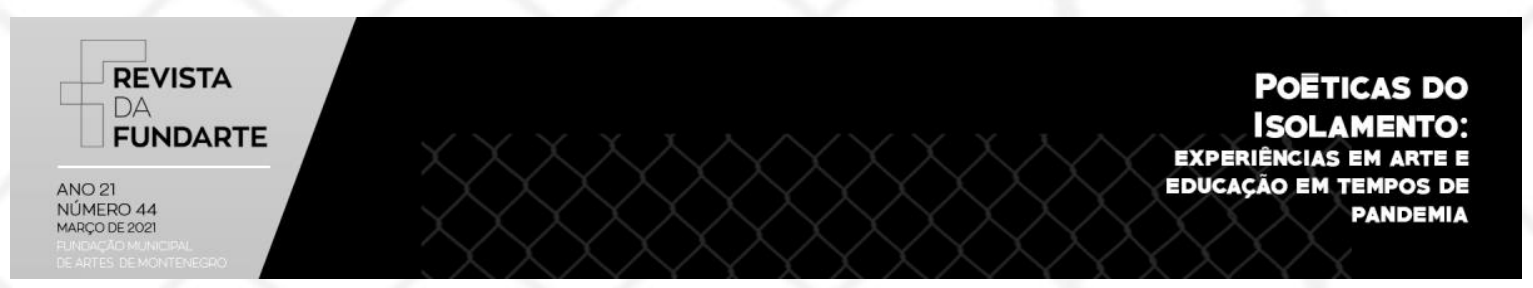

KASTRUP, V. O lado de dentro da experiência: atenção a si mesmo e produção de subjetividade numa oficina de cerâmica para pessoas com deficiência visual adquirida. Psicol. cienc. prof., Brasília, v. 28, n. 1, p. 186-199, 2008. Disponível em: http://www.scielo.br/scielo.php?script=sci arttext\&pid=S141498932008000100014\&lng=en\&nrm=iso . Acesso em: 20 Jun. 2020.

MACHADO, R. A arte da palavra e da escuta. São Paulo: Editora Reviravolta, Edição rev. e amp. do livro Acordais,2015.

MATOS, G.A. A palavra do contador de histórias. 2.ed. São Paulo: WMF Martins Fontes, 2014.

RIBEIRO, S. R. O. e VILAÇA, M. L. C. Tecnologia, Linguagem e Educação a Distância. In: VILAÇA, M. L. C. e ARAÚJO E. V. F. (Orgs.). Tecnologia, Sociedade e Educação na Era Digital. Duque de Caxias, RJ: UNIGRANRIO, 2016.

SANTAELLA, L. A relevância da arte-ciência na contemporaneidade. In Ramos, L. F.(Org.). Arte e ciências: abismo de rosas. São Paulo: Abrace, 2012.

SCHERMACK, K. Q. A contação de histórias com arte performática na era digital: convivência em mundo de encantamento. Anais de evento, 2013. Disponível em: https://editora.pucrs.br/anais/IIICILLIJ/Trabalhos/Trabalhos/S10/keilaschermack.pdfJ un. Acesso em: 12 Jun. 2020.

AMORIM, Maria Cecília Silva de; FIGUEIREDO, Valéria Maria Chaves de. Cenário digital e a contação de histórias: (re)significa(ações) de um projeto artístico-pedagógico. Revista da FUNDARTE. Montenegro, p.01-20, ano 21, no 44, janeiro/março de 2021.

Disponível em: http://.seer.fundarte.rs.gov.br/index.php/revistadafundarte/index> 30 de março de 2021. 